GEORGES BATAILLE 



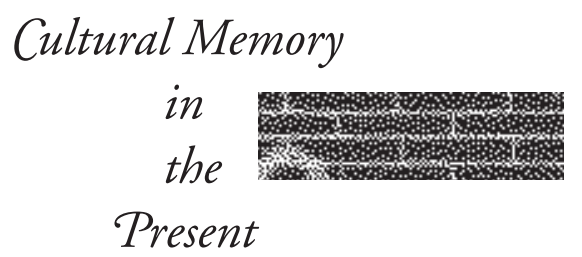

Mieke Bal and Hent de Vries, Editors 



\section{GEORGES BATAILLE}

Phenomenology and Phantasmatology

\section{Rodolphe Gasché}

Translated by Roland Végsö

Foreword to the English edition

by David Farrell Krell

STANFORD UNIVERSITY PRESS

STANFORD, CALIFORNIA 
Stanford University Press

Stanford, California

English translation, Foreword, Preface to the English Edition, and Introduction (C) 2012 by the Board of Trustees of the Leland Stanford Junior University. All rights reserved.

Originally published in German (Peter Lang) under the title System und Metaphorik in der Philosophie von Georges Bataille (C) 1978, Rodolphe Gasché.

No part of this book may be reproduced or transmitted in any form or by any means, electronic or mechanical, including photocopying and recording, or in any information storage or retrieval system without the prior written permission of Stanford University Press.

Printed in the United States of America on acid-free, archival-quality paper

Library of Congress Cataloging-in-Publication Data

Gasché, Rodolphe, author.

[System und Metaphorik in der Philosophie von Georges Bataille. English.]

Georges Bataille : phenomenology and phantasmatology / Rodolphe Gasché ; translated by Roland Végső.

pages $\mathrm{cm}$. - (Cultural memory in the present)

"Originally published in German under the title System und Metaphorik in der Philosophie von Georges Bataille.”

Includes bibliographical references and index.

ISBN 978-0-8047-7606-6 (cloth : alk. paper)

ISBN 978-0-8047-7607-3 (pbk. : alk. paper)

I. Bataille, Georges, I897-1962-Philosophy. 2. Phenomenology. I. Végső,

Roland, translator. II. Title. III. Series: Cultural memory in the present.

PQ2603.A695Z674I3 2012

848 '.91209-dc23 